Volume 9, Issue 2 (Summer 2017)

\title{
Pieter de Molijn (1597-1661): A Dutch Painter and the Art Market in the Seventeenth Century
}

Marion Boers

m.e.w.boers@hum.leidenuniv.nl

Recommended Citation:

Marion Boers, "Pieter de Molijn (1597-1661): A Dutch Painter and the Art Market in the Seventeenth Century," Journal of Historians of Netherlandish Art 9:2 (Summer 2017) DOI: 10.5092/ jhna.2017.9.2.5 Available at https://jhna.org/articles/pieter-de-molijn-dutch-painter-art-market-seventeenth-century/

Published by Historians of Netherlandish Art: https://hnanews.org/ Republication Guidelines: https://jhna.org/republication-guidelines/

Notes: This PDF is provided for reference purposes only and may not contain all the functionality or features of the original, online publication. This PDF provides paragraph numbers as well as page numbers for citation purposes.

ISSN: 1949-9833 


\title{
Pieter de Molijn (1597-1661): A Dutch Painter and the Art Market in the Seventeenth Century
}

\author{
Marion Boers
}

Pieter de Molijn is considered by present-day art historians to be one of the founders of what is referred to as the tonal phase of naturalistic Dutch landscape painting, a position largely attributable to his Landscape with Dunes painted in 1626. Nevertheless, art historians such as Wolfgang Stechow have suggested that his paintings after 1630 were old-fashioned, lacked originality, and exhibited no further artistic development, and therefore they typify him as merely an epigone of Jan van Goyen and Salomon van Ruisdael. For most of these art historians, innovation seems to be the most important criterion on which to grant painters a place in the art-historical canon. Contemporary sources, however, indicate that de Molijn deserves as much attention as the more recognized artist Jan van Goyen. These sources prove that de Molijn enjoyed a solid reputation right up until his death in 1661. He was active in broadening the art market by producing monochrome landscapes and finding new ways to sell them to a wider public. In addition, Arnold Houbraken and other connoisseurs valued his later, more delicate and colorful landscapes. These were bought by collectors who appreciated de Molijn's craftsmanship and the works' subtle references to famous landscape painters of the past. Pieter de Molijn developed a successful business model by simultaneously working in different styles for different clients, thus securing his niche in a competitive art market.

\section{Pieter de Molijn as a Pioneer of the "Tonal" Landscape}

Arnold Houbraken (1660-1719) wrote at the beginning of the eighteenth century that "Pieter de Molijn was an accomplished painter of landscapes, clear in the way he rendered distances and glowing in his foregrounds." 'Soon after Houbraken wrote these words, de Molijn was forgotten as a painter. Primarily his drawings - rather than his paintings-became highly valued during the eighteenth and nineteenth centuries. ${ }^{2}$

2 Only since the mid-1960s has Pieter de Molijn come to be recognized as one of the leading figures of early seventeenth-century Dutch landscape painting, along with Esaias van de Velde (1596-1656) and Jan van Goyen (1587-1630). In 1966, Wolfgang Stechow was the first to emphasize the importance of de Molijn's Landscape with Dunes and a Sandy Road (1626) for the artistic development of Dutch landscape painting (fig. 1). This simple landscape represents an early stage of the style known as the tonal phase of seventeenth-century Dutch painting, in which vistas of 
the countryside are characterized by a broad painterly manner and a restricted palette of grays, greens, browns, dull yellows, and blues. ${ }^{3}$ According to Stechow, de Molijn should be considered a pioneer of this innovation in landscape painting, although he emphasized that after 1630 de Molijn's work became regressive and outmoded. ${ }^{4}$ By that time, he argued, Salomon van Ruisdael (ca. 1602-1670) and Jan van Goyen were the leading artists, while de Molijn's work lacked inspiration.

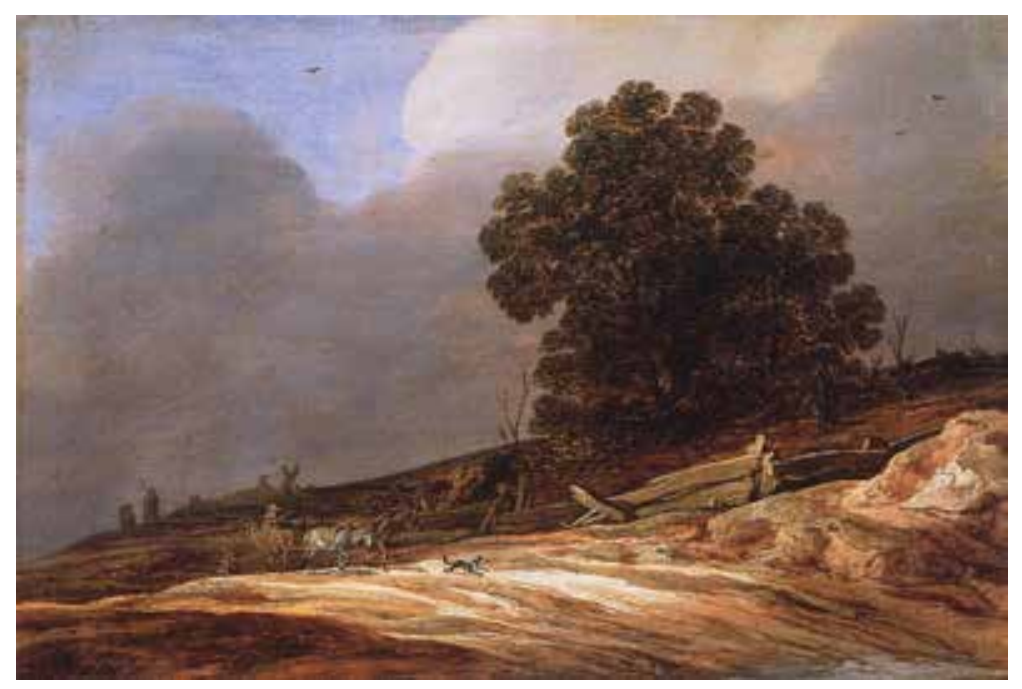

Fig. 1 Pieter de Molijn, Landscape with Dunes and a Sandy Road, oil on panel, $26 \times 36 \mathrm{~cm}$, signed and dated PMolyn 1626. Braunschweig, Herzog Ulrich-Museum, inv. 338 (artwork in the public domain)

In 1969, Laurens Johannes Bol also discussed de Molijn as an artist in the shadow of his famous contemporaries. But significantly, he remarked that at present little appreciation existed for the work he completed after 1630. That was unfortunate because, according to him, these later landscapes had a special quality of their own that could not be compared to the work of the van Goyen school. ${ }^{5}$ Bol pointed out that de Molijn's landscape of 1647, now in the Frans Hals Museum in Haarlem, has a richer color scheme than van Goyen's paintings from the same period (fig. 2). ${ }^{6}$

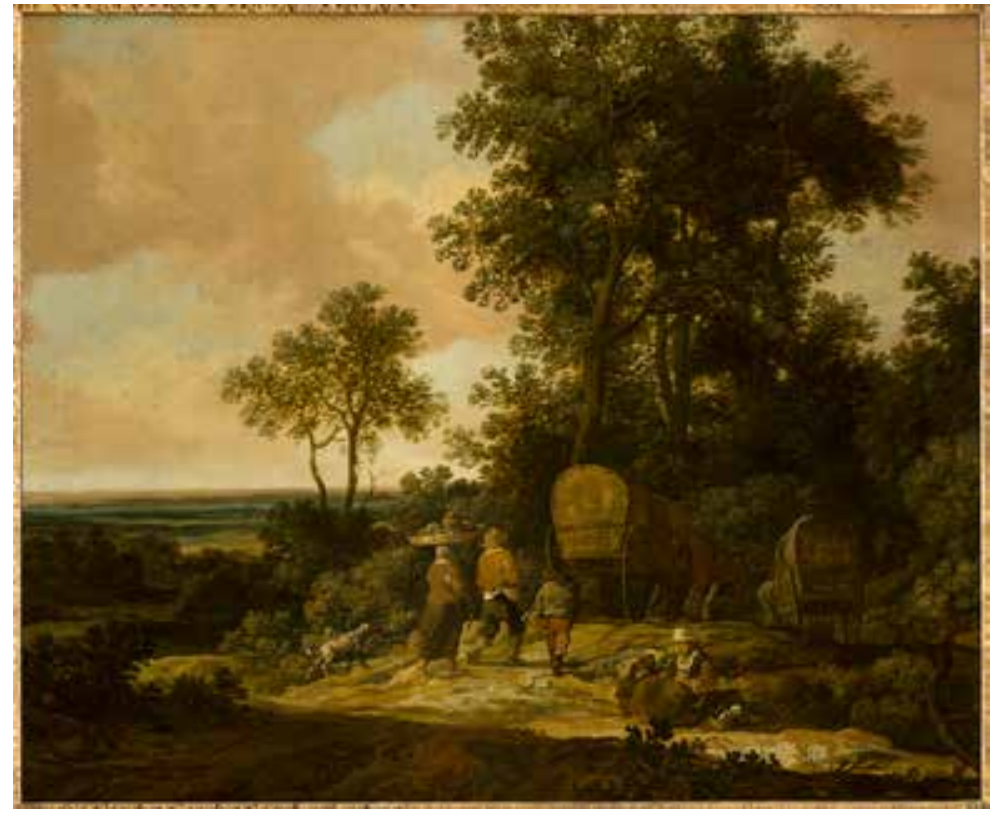

JHNA 9:2 (Summer 2017)
Fig. 2 Pieter de Molijn, Peasants Returning Home, oil on canvas, 76 × $93.5 \mathrm{~cm}$, signed and dated PMolyn 1647. Haarlem, Frans Hals Museum, inv. 0.s. 60-52 (artwork in the public domain; photo: Margareta Svensson) 
In 1987, Eva Jeney Allen published her dissertation on de Molijn. She described the artist as a transitional figure in the history of Dutch landscape painting, whose oeuvre formed a bridge between the mannerist art of the previous generation and the new naturalism of the seventeenth century. Allen characterized him as a versatile artist who painted diverse subjects and worked in several different styles at the same time. ${ }^{7}$ She maintained that de Molijn was a founder and perpetuator of the tonal style, along with Esaias van de Velde and Jan van Goyen. On the other hand, she pointed out that de Molijn's work continued to display the decorative Flemish and Dutch mannerist tendencies of previous epochs. Allen considered de Molijn a painter who inspired other artists with traditional ideas. ${ }^{8}$ She also emphasized the importance of the formative years between 1616 and 1625 for his artistic development and commented that he often fell back on the works he had studied during this crucial period of his life, among them landscapes by Abraham Bloemaert (1564-1651), Esaias van de Velde, and Roelant Savery (1576-1639). ${ }^{9}$

Finally, in 1991, Hans Ulrich Beck discussed Pieter de Molijn's paintings in his Künstler um Jan van Goyen. As the title of his book suggests, he looked upon de Molijn as a painter in the shadow of his great contemporary Jan van Goyen, even as he acknowledged de Molijn's individual qualities. ${ }^{10}$ Stechow, Allen, and Beck observed that de Molijn produced hardly any dated paintings or drawings between 1630 and 1640. Stechow even went so far as to call de Molijn "an enigmatic master" because of this presumed lack of productivity. ${ }^{11}$

From this we can conclude that scholars do not always agree on de Molijn's place among contemporary landscape painters. They all mention his role as a pioneer of the tonal phase of Dutch landscape around 1625, but their viewpoints differ on his position after 1630. Some equate his talents with those of Jan van Goyen, Salomon van Ruisdael, and Esaias van de Velde, however more often his work after 1630 is considered mediocre and lacking the originality of his rivals. The two most important standards present-day art historians have applied to de Molijn's work are originality (or lack thereof) and imitation, the first used as a positive qualification (when it is present) and the second negative. Terms often used in this context are influence and inspiration. De Molijn deserved a place among the famous painters of the Golden Age because around 1625 he was a trendsetter who influenced Jan van Goyen and was a source of inspiration to many other painters. However, after 1630 he can be considered an epigone of such artists as van Goyen and van Ruisdael as he was inspired by them rather than acting as a source of inspiration himself. Moreover, he became regarded as outmoded later in life because he fell back on the sources of inspiration of his formative years. De Molijn's artistic importance is not so much determined by the quality of his work as by what these art historians considered to be his innovative approach to landscape painting in the period around 1625.

7 Eric Jan Sluijter recently published the first volume of Rembrandt's Rivals. In this excellent study, he shows the diversity in Amsterdam history painting, how artists distinguished themselves from others, and how they tried to build a reputation. In the introduction, Sluijter argues that one should not approach art in terms of influence, nor should scholars use such words as inspiration. Both deny the artist's agency. Sluijter prefers to apply the concept of artistic competition, a conscious rivalry that is related to securing a social and economic position in the art market. He emphasizes that enormous pressure on the art market led to artistic competition at all levels. Because of the varied audience, an extensive range of types, quality, and price levels developed. 
In this highly competitive market, all artists were concerned with securing their niche, and their reputations were a key element in the process. As a result, such questions arose as: how should I position myself, what types of paintings should I produce, and how do I build a reputation? ${ }^{12}$

From 1615 onward, Haarlem distinguished itself from other artistic centers in Holland because of its relatively large production of landscapes. ${ }^{13}$ Artists there had to take up the same kinds of challenges regarding the market as the Amsterdam history painters analyzed by Sluijter. This article aims to use Sluijter's approach and method to define the reputation of Pieter de Molijn in comparison with that of Jan van Goyen. The article addresses a central question: what was de Molijn's reputation as a landscape painter during his lifetime and how should we define his position in the school of landscape painting that flourished in Haarlem during the first half of the seventeenth century? Were originality and innovation the decisive factors that determined the reputation of such painters as de Molijn or did other standards influence their success? In other words, was de Molijn's reputation solely based on his early production of monochrome landscapes? The answer emerges from what we know about his life and work through such contemporary sources as documents in archives, city chronicles, and artist biographies.

\section{Pieter de Molijn: Biography}

All the important facts on the life of Pieter de Molijn were published in 2006 by Irene van Thiel-Stroman in the catalogue of the Frans Hals Museum. I will restrict this biography to those facts and circumstances that relate to his artistic development, and his position in society and among his fellow artists. ${ }^{14}$

10 Pieter de Molijn was baptized on April 6, 1595, in Austin Friars Church in London. His parents originally came from Brussels and finally moved to Holland during the first decade of the seventeenth century. The names of Pieter de Molijn's teachers are unknown, but he was most likely placed in the charge of a painter who originated from Flanders, as was the usual procedure in immigrant circles. ${ }^{15}$ His work shows that he studied the paintings of Roelant Savery and especially the prints of Esaias van de Velde and Jan van de Velde II (1593-1642), as well as other artists working in Haarlem, such as the painter/engravers Willem Buytewech (1591/92-1624) and Hercules Seghers (ca. 1589-ca. 1638).

11 In 1616, de Molijn was recorded as an independent master painter in the Haarlem Guild of Saint Luke. At that time Haarlem was one of the most important centers of artistic production in Holland. New types of painting were being developed, among them the so-called naturalistic Dutch landscape. Prints and the interaction between printmaking and painting were the decisive factors in the development of early Dutch landscape painting. As Melanie Gifford pointed out in 1998, Esaias van de Velde was the key figure in introducing what became a growing naturalism in Dutch landscape painting. The trend continued a decades-old tradition from the Southern Netherlands, both in technique and in the naturalistic representation of the Dutch landscape. Esaias van de Velde moved to The Hague in 1618 and in response to the court-influenced local market he began to paint more graceful, arcadian landscapes, moving back and forth easily between the two modes. ${ }^{16}$ 
12 Between 1616 and 1625, de Molijn made designs for several prints that were engraved by other artists, but we do not know of any signed paintings dating before $1625 .{ }^{17} \mathrm{He}$ may have concentrated first on drawing and designing prints before turning to painting. ${ }^{18}$ It is still unclear when de Molijn started to paint landscapes. Perhaps it took him some time to recognize their potential. As a young artist, between 1616 and 1625, he responded to the artistic challenges of his time and compiled a memory bank of images by his favorite artists, including Abraham Bloemaert, Gillis van Coninxloo (1544-1607), David Vinckboons (1576-1632), Roelant Savery, and especially Esaias van de Velde. Allen emphasizes that these painters and printmakers had a profound influence on the artistic choices de Molijn was to make later in life. Such seventeenthcentury sources as probate inventories show that he experimented with different types of landscapes, for example bataljes that remind us of Esaias van de Velde.

13 In the period around 1630 de Molijn was a respected artist. ${ }^{19} \mathrm{He}$ could afford to buy a house on the Oude Gracht in Haarlem for the sizeable sum of 3,100 guilders. Moreover, he was appointed dean of the Haarlem Guild of Saint Luke in 1632. Previously, this leading position had always been held by artists of local, mostly Roman Catholic, descent; Pieter de Molijn was a Protestant and the first son of an immigrant to hold this honorary position in the guild. ${ }^{20}$

14 De Molijn became dean during a time of fierce competition, both within the Haarlem artistic community itself as well as from other Dutch towns. In the years that followed, Pieter de Molijn and Salomon van Ruisdael both took a stand for offering new opportunities for local artists. In around 1625, de Molijn became one of the first to recognize the commercial possibilities of tonal landscapes, which had relatively low production costs. Together with a small group of artists, he advocated for granting permission to sell these relatively cheap paintings on a larger scale, for example, by organizing auctions and lotteries. He argued that these market strategies would create a whole new range of potential clients, buyers who had previously not been able to afford paintings, particularly paintings of good quality. This would open up new markets to artists who had just started their business, as well as to lower cost works by de Molijn himself and other artists who were following in the footsteps of market leaders. ${ }^{21}$

15 No sign can be found of any decline in originality within de Molijn's body of work after 1630 (the decline presumed by Stechow and others) nor any loss of respect by guild members. He was reappointed to the board of governors of the organization, both as vinder and dean, in 1637, 1638,1645 , and $1649 .{ }^{22}$ His position as an appraiser of art collections points to the fact that connoisseurs valued his artistic opinion. ${ }^{23}$ Thus after 1630, de Molijn was still highly respected not only by local artists but also by the public.

16 Allen suggests that the enigma of the 1630s, namely the lack of signed and dated paintings and drawings - according to her indicating diminished production-can be explained by de Molijn's activities as dean of the Guild of Saint Luke. ${ }^{24}$ She overlooks the fact that this was primarily an unpaid honorary position. Artists would not have agreed to fulfill these duties if this prevented them from running their businesses. On the contrary, one can imagine that being dean brought esteem to a painter and may even have resulted in more work. Not only did de Molijn promote ways of selling cheaper pictures, he was also one of the artists who contributed to auctions and lotteries. ${ }^{25}$ This indicates that de Molijn himself produced low-cost paintings and actively used the 
selling methods he advocated. It is therefore unlikely that his production would have decreased as a result of his activities for the guild.

17 Pieter de Molijn passed away in 1661 in his house on the Oude Gracht in Haarlem. Various primary sources show he was a man of wealth and esteem. The respect bestowed by his community allowed him to fill several honorary functions apart from dean of the Guild of St. Luke: he was appointed deacon of the Dutch Reformed Church and grachtmeester of the Crayenhorstergracht quarter. He was a respected painter outside his hometown as well-pupils came to him from Alkmaar (Allart van Everdingen [1617-1675]) and Deventer (Gerard Ter Borch [1617-1681]). He enjoyed greater success than Jan van Goyen, who ended up bankrupt in The Hague, and Salomon van Ruisdael, who was forced to take on a second business to make ends meet.

\section{Reputation and Artistic Status}

18 The reputation of Jan van Goyen, Salomon van Ruisdael, and Pieter de Molijn during the Golden Age is affirmed by the appearance of their names in such primary sources as city chronicles and volumes of artists' biographies - witness the monumental work of Arnold Houbraken, written at the beginning of the eighteenth century-and in the praise used to refer to them. Sluijter outlines Jan van Goyen's reputation as starting with the reference to him in Mijn jeugd, the autobiography of Constantijn Huygens (1596-1687). ${ }^{26}$ The first biography of Jan van Goyen was published by the Leiden city secretary and writer Jan Orlers (1570-1646) in his city chronicle in $1641 .{ }^{27}$ Orlers was the source for the long biography of van Goyen in Houbraken's Groote Schouburg at the beginning of the eighteenth century.

19 De Molijn also received a lot of attention in written sources from the Golden Age, although slightly less than Jan van Goyen. His name appears for the first time in Het lof der stad Haerlem in Hollandt, an anonymous publication of 1621 that is usually ascribed to Samuel Ampzing (15901631). ${ }^{28} \mathrm{He}$ is the final artist whom Ampzing considers worth mentioning; his name follows that of the glass painter Jan Philipszn van Bouckhorst (1598-1631), probably because de Molijn was still primarily a printmaker at that time. In 1628 Ampzing published a more detailed history of Haarlem, and he mentioned de Molijn, together with the now almost unknown landscape painter Jan Jacobszn Guldewaghen (?-1610). ${ }^{29}$ Ampzing wrote about de Molijn's stout(daring) brushwork and his handeling (style of painting). Following in Ampzing's footsteps, Theodorus Schrevelius (1572-1649) published his history of Haarlem in 1648, in which he mentioned de Molijn as a landscape painter. He grouped him together with Cornelis Vroom (ca. 1591-1661) and Salomon van Ruisdael, but with the qualification that de Molijn and Cornelis Vroom were uytsteckend meesters (excellent masters), whereas van Ruisdael was evaluated as a gemeen schilder (a mediocre painter) just like the now almost completely forgotten Reyer Claeszn Suycker (ca. 1577-ca. 1636).$^{30}$ It is remarkable that Schrevelius describes de Molijn as a painter whose skills are comparable to those of Cornelis Vroom, who is known for his technical refinement. But Vroom never painted tonal landscapes executed in broad, vivid brushwork, the kind of works for which Jan van Goyen and Salomon van Ruisdael are now famous. ${ }^{31}$

20 We can conclude from this that city chronicles mentioned Jan van Goyen, Salomon van Ruisdael, and Pieter de Molijn during their lifetimes. Orlers's biography of Jan van Goyen is much more 
elaborate than the biographies of either Pieter de Molijn or Salomon van Ruisdael by Ampzing and Schrevelius. However, these discrepancies are, at least partly, the result of differences in the perspective that was chosen by the authors, not by the fact that van Goyen was more famous than his two contemporaries. Remarkably enough, Schrevelius in 1648 ranked de Molijn above Salomon van Ruisdael and compared his style to that of Cornelis Vroom.

In around 1650, both van Goyen and de Molijn were considered fine landscape painters, but this changed during the final quarter of the seventeenth century. By that time van Goyen was well established as a painter who specialized in monochrome landscapes executed with quick, vivid brushwork. $^{32}$ This was also the case at the beginning of the eighteenth century, when Houbraken copied Orlers's long biography of Jan van Goyen in his Groote Schouburgh. He characterized Pieter de Molijn's work in one sentence, the opening words of this article: "(he) was an accomplished painter of landscapes, clear in the way he rendered distances and glowing in his foregrounds." ${ }^{33}$ By 1720, when Houbraken was writing, van Goyen was still well known and worth a rather long biography, but by then Pieter de Molijn was almost forgotten.

22 Other primary sources with insight into the reputation of artists during their lifetimes are probate inventories, which indicate the artist's reputation with the general public. In the case of Jan van Goyen, Sluijter concluded that no other artist was mentioned so frequently in probate inventories. ${ }^{34}$ It is notable that his name not only occurs in the cities where van Goyen lived and worked but in almost all the other large towns in Holland as well. Landscapes by van Goyen seem to have been easily recognizable by these appraisers with or without the artist's signature. One can argue that his name may have become a generic term for a certain type of landscape. That van Goyen stood for a certain type of work and level of quality, and therefore a value worth mentioning, is illustrated by the fact that in some cases van Goyen is the only name that occurs in probate inventories among otherwise anonymous painters. The same is true of Pieter de Molijn, although not of Salomon van Ruisdael..$^{35}$

23 Van Goyen may have had a style that was easy to recognize but remarkably enough Pieter de Molijn seems to have been almost his match. Sometimes both artists were named in the same inventory. We can conclude from this that appraisers recognized the differences in style but, more importantly, that the names of both painters were worth noting down; apparently this added to the value of these landscapes.

24 A detailed analysis of probate inventories mentioning Jan van Goyen and/or Pieter de Molijn in various large cities in Holland leads to a number of conclusions. Jan van Goyen's name occurs in an inventory as early as 1627 and that of de Molijn in 1629. This implies that their paintings were recognized and worth mentioning early on in their careers. In Haarlem, Jan van Goyen was named most frequently of all artists until 1670, but Pieter de Molijn came second. Salomon van Ruisdael who, as has already been pointed out, was described in 1648 by Schrevelius as a mediocre painter, was not mentioned once in inventories before 1658, either in or outside his home town of Haarlem. This changed between 1658 and 1670, which seems to indicate that his reputation grew after his death. ${ }^{36}$ 
In Willemijn Fock's selection of Leiden inventories, Jan van Goyen is named frequently and Pieter de Molijn again comes second. ${ }^{37}$ Salomon van Ruisdael was not mentioned once in this selection of Leiden inventories.

26 Before 1650 the names of both van Goyen and de Molijn occur frequently in probate inventories in Amsterdam. ${ }^{38}$ It is remarkable that de Molijn was mentioned more often in inventories before 1635 than van Goyen. There was a significant change between 1650 and 1681, when van Goyen was named thirty-three times in twenty-three inventories and de Molijn "only" nineteen times in twelve. The Amsterdam landscape painter Barend Theunisz Drenth owned works by van Goyen and de Molijn in 1629, as did many other Amsterdam art collectors. ${ }^{39}$ This not only suggests that clerks could ascertain the different styles, but that both painters were valued by these Amsterdam owners. ${ }^{40}$ Salomon van Ruisdael is not mentioned once in the inventories published by John Michael Montias.

This leads to the conclusion that Pieter de Molijn's landscapes were recognized by clerks not only in Haarlem, but in Amsterdam, Leiden, and The Hague as well. ${ }^{41}$ Unlike that of Jan van Goyen, de Molijn's name does not occur in probate inventories in such cities as Delft and Rotterdam.

Until around 1650 the reputations of van Goyen and de Molijn were more or less comparable, but from that time onward van Goyen became the rising star. Moreover, we can conclude that Salomon van Ruisdael is only mentioned once or twice in Haarlem during the second half of the seventeenth century although he seems to have been as productive in making his tonal landscapes. This indicates that appraisers did not think mentioning his name would add to the value of the painting, and this is all the more remarkable because Salomon van Ruisdael is considered to be one of the most important representatives of the tonal phase of Dutch landscape painting by present-day art historians. ${ }^{42}$

\section{Owners}

29 Sluijter shows the significance for artists of being represented in the collections of the rich and the powerful. According to him, the role of art lovers and connoisseurs was crucial for an artist's reputation. Samuel van Hoogstraten emphasized that it was important for an artist to have good connections and for his paintings to be sold to influential clients. This was a valuable form of advertising. If your work was held in high esteem by wealthy merchants and well-known art collectors, you could acquire fame and, more importantly, you could ask a higher price for your paintings. ${ }^{43}$ It was therefore profitable for painters and good for their reputation to give or sell their works to collectors and people in high places.

30 Van Goyen's landscapes are a case in point. A wide range of inventories mention them: those of craftsmen, small merchants, aristocrats, and art collectors. Some buyers had only a few guilders to spend on luxury, while others were incredibly rich. Although these landscapes were not the most (monetarily) valued possessions for art lovers, they must have particularly appreciated the artistic qualities and the atmospheric effects van Goyen achieved with his quick brushwork and an almost monochrome palette. The relatively low purchase price allowed connoisseurs to buy several paintings by van Goyen. ${ }^{44}$ The fact that the upmarket Amsterdam art dealer Johannes de Renialme also 
traded in works by van Goyen indicates that his landscapes were also bought by the city elite. ${ }^{45}$

31 In this respect, Pieter de Molijn again was a match for Jan van Goyen. Some of the Haarlem owners were magistrates or belonged to the local gentry. ${ }^{46}$ Outside Haarlem, the collector Jan van de Capelle not only had works by Jan van Goyen in his constcamer but a nachtje (a little night landscape) and fifty-seven drawings by Pieter de Molijn as well. ${ }^{47}$ Ferdinand Bol's (1616-1680) contribution to his marriage with Anna van Arckel (died 1680) in 1669 was a sizeable collection of paintings, consisting of, among others, works by his teacher Rembrandt (1606-1669) and by such artists as Jan Porcellis, Willem Kalf (1619-1693), and Pieter de Molijn. ${ }^{48}$ De Molijn was also represented in the estate of the art dealer Johannes de Renialme in 1657, although it has to be admitted that the landscapes by de Molijn and van Goyen are among the lower priced works in this estate. ${ }^{49}$

32 De Molijn's reputation among art lovers is underlined by the special visit paid to the artist's workshop in Haarlem in 1647 by the Utrecht connoisseur and collector Willem Vincent van Wyttenhorst (ca. 1613-1674). He bought a marine painting with the modest dimensions of $28.5 \times 55 \mathrm{~cm}$ for 40 guilders. This emphasizes once more that de Molijn's reputation with art lovers had not diminished after $1630 .^{50}$

\section{The Value of Landscapes by Pieter de Molijn, Jan van Goyen, and Salomon van Ruisdael during the Seventeenth Century}

33 In the open market, success or failure was determined on the basis of an artist's reputation. Prospective customers recognized differences in quality, novelty, and ingenuity. The "ranking" of an artist had immediate consequences for the prices they could ask for their pictures and for the value of their work. During the seventeenth century, prices were no longer solely based on size, labor, or materials but also on a painter's reputation. A tonal landscape could be made in less than a day using inexpensive pigments and other materials, and thus the production costs came to only a few guilders. As we will see, people appreciated the artistic value of the unique way the atmosphere of the Dutch landscape was represented by these artists, and they were willing to pay a much higher price depending on the artist's reputation.

34 Sluijter analyzed the value of landscapes by Jan van Goyen and came to the following conclusions. Before 1660, the average price was 19.2 guilders. The cheapest paintings were valued at only a few guilders each, the most expensive at 54 guilders. ${ }^{51}$ Sluijter maintains, however, that these valuations were usually not comparable to the amount that was paid directly to van Goyen for his landscapes. He suggests that the prices on lottery lists may indicate the original purchase price. ${ }^{52}$ Sluijter concludes that clients were expected to pay around 40 guilders for an averagesize landscape in the artist's shop, twice the average value if the work were acquired from other sources. ${ }^{53}$

35 There are thirty-one valuations of paintings by Pieter de Molijn in inventories and auctions dating before $1665 .{ }^{54}$ In 1647 the highest appraisal of a painting by de Molijn was 50 guilders in the estate of the Amsterdam merchant Isaack van Gherwen. ${ }^{55}$ The lowest valuation was 1 guilder in 1660 in the estate of the Amsterdam frame-maker Jan Willemszn Bus. ${ }^{56}$ Half of these valuations were 
higher than 10 guilders, and most paintings assessed lower than 10 guilders were described as "small landscapes." ${ }^{57}$ Until 1665 the average value of landscapes by de Molijn was 18.85 guilders, a marginal difference compared to the 19.2 guilders calculated by Sluijter for paintings by Jan van Goyen. ${ }^{58}$ After de Molijn died, the prices for his paintings dropped to an average of 8.37 guilders.

36 Seventeen paintings by de Molijn were advertised in three different lottery lists between 1634 and 1645. The prices are comparable to those for works by Jan van Goyen. ${ }^{59}$ The average price for landscapes by de Molijn in lotteries is 53.66 guilders, much higher than the 38.1 guilders for paintings by van Goyen, but this is mostly due to the fact that some of his landscapes were described as large pieces. ${ }^{60}$ It is remarkable that this average is comparable to the highest valuation in the probate inventory of Isaack van Gherwen mentioned above. ${ }^{61}$ We can conclude that, during his lifetime, the paintings of Pieter de Molijn had a value and an original purchase price that were comparable to those of Jan van Goyen. This assumption can be confirmed by an analysis of assessed inventories that mention work by both van Goyen and de Molijn. In general, these valuations appear to be comparable, although work by van Goyen is usually valued slightly higher than that of de Molijn. ${ }^{62}$

Schrevelius judged Salomon van Ruisdael a second-rate artist in 1648. His evaluation is confirmed by the prices that were mentioned for his paintings at that time, which were worth approximately half the value of de Molijn's landscapes. ${ }^{63}$ This supports Schrevelius's remark from 1648 that Pieter de Molijn had excellent qualities as a painter, but that Salomon van Ruisdael's skills were considered to be average.

We can conclude from these data that between 1630 and 1650 the prices and values of de Molijn's landscapes almost equaled those of Jan van Goyen and therefore little difference can be discerned between their reputations as expressed in valuations. Moreover, these prices and valuations seem to confirm the remark by Schrevelius that it was Salomon van Ruisdael who was considered a mediocre landscape painter rather than de Molijn. Finally, the large gap between the lowest and highest valuations cannot be explained only by the paintings' sizes; quality differences must also have played a role. In other words, it is probable that these higher and lower prices and valuations indicate different kinds of paintings.

\section{De Molijn's Business Model}

39 In their articles on Esaias van de Velde and the art market during the first decades of the seventeenth century, Melanie Gifford and Eric Jan Sluijter observed that van de Velde worked in different techniques for various clients. His oeuvre includes paintings executed in a narrative style with a refined technique, on the one hand, and, on the other, schematic landscapes executed with loose brushwork, thin paint layers, and fewer figures, which thus were much cheaper to make. They suggest that van de Velde made these paintings for different target groups. ${ }^{64}$ It seems that Esaias van de Velde functioned as an example for de Molijn not only because of his prints and paintings but also for the organization of his business. De Molijn added figures to his landscapes in much the same way that van de Velde did: often they are painted so thinly that the landscape shines through. Another sign of the commercialization of his production methods is his frequent use of basic concepts for his landscapes, such as a panorama of dunes (fig. 3) or a river landscape 
with a bridge, with slight variations in the form of an element added here or there (fig. 4). A third sign of commercial production is that de Molijn often reused certain elements in his paintings, such as covered wagons (fig. 5: compare fig. 2). Working with basic concepts and variations, recycling motifs, employing loose brushwork, and limiting the amount of colors lowered the production costs of paintings, making them available for a wider public.
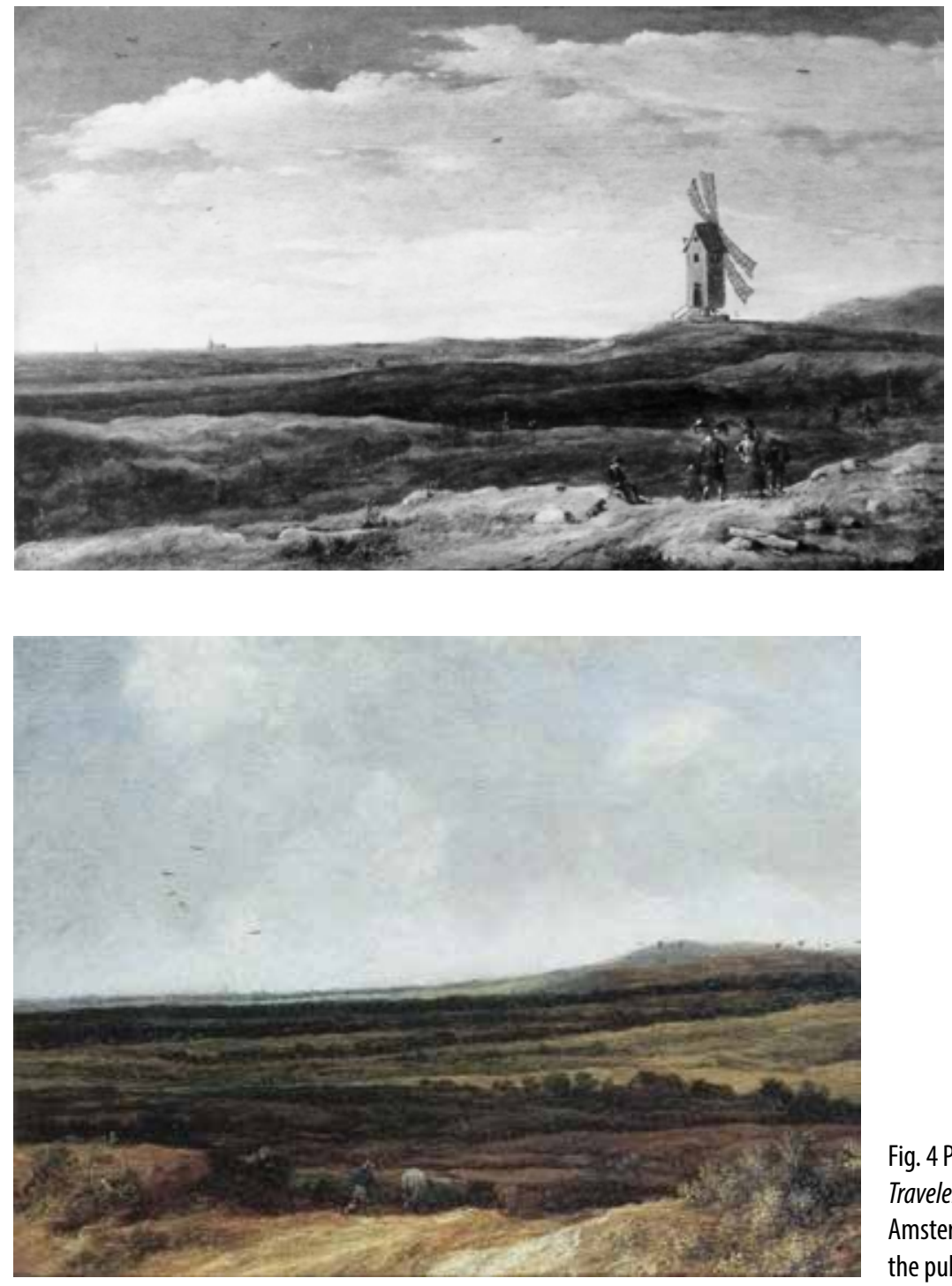

Fig. 3 Pieter de Molijn, Landscape with Dunes and Travelers, oil on panel, $29 \times 50 \mathrm{~cm}$, signed PM. Poznan, Museum Marodowe Poznaniu, inv. Mo 818 (artwork in the public domain)
Fig. 4 Pieter de Molijn, Landscape with Dunes and Travelers, oil on panel, $28.6 \times 36.8 \mathrm{~cm}$, unsigned. Auction, Amsterdam, Christie's, May 14, 2002, no. 37 (artwork in the public domain)

From 1625 on, de Molijn made paintings in both techniques: colorful narrative landscapes executed with technical refinement and monochrome paintings, finished within a day, in a technique that was perfect for rendering the atmosphere and the humidity of the Dutch landscape. The famous tonal Landscape with Dunes of 1626 in Braunschweig (see fig.1) is a fine example of de Molijn's commercial production based on the early techniques and color schemes of Esaias van de Velde and Jan Porcellis. This work was intended for a different clientele from the colorful paintings with many figures such as Prince Maurits and Frederick Hendrick, dating from 1625, or the history subjects set 


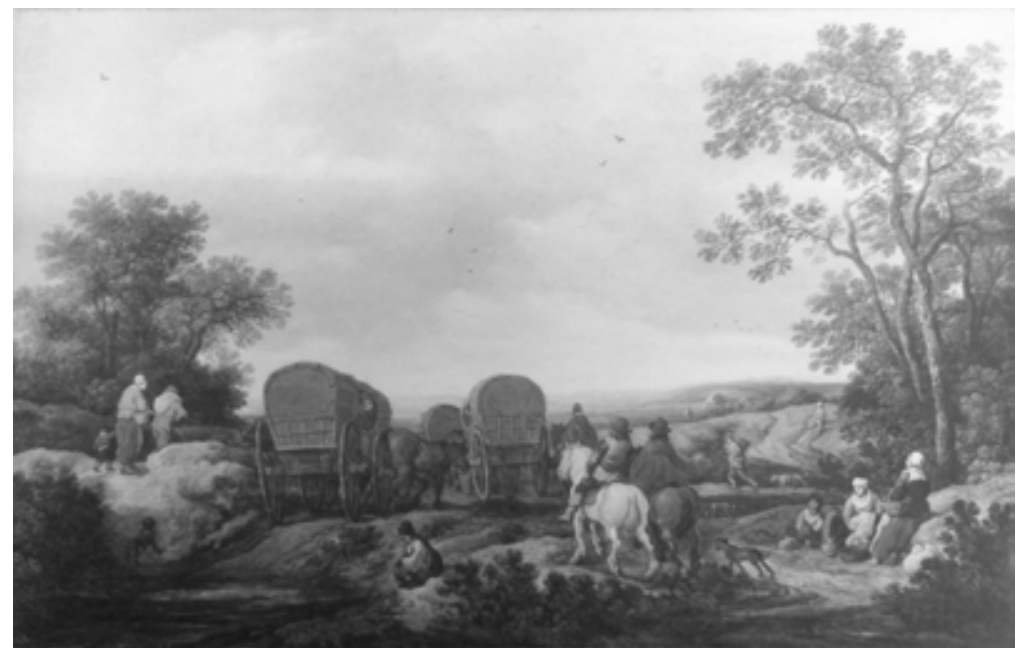

Fig. 5 Pieter de Molijn, Travelers in Landscape with Dunes, oil on canvas, $39.5 \times 61 \mathrm{~cm}$, signed and dated PMolyn 1647. Whereabouts unknown (artwork in the public domain)

in a landscape that we find in the probate inventory of the Amsterdam silk merchant Joris van Oorschot in $1671 .^{65}$ This points to de Molijn's production of paintings for different segments of the contemporary art market at the same time.

41 De Molijn seldom signed or dated the monochrome landscapes intended for the open market. Eva Jeney Allen pointed out that these paintings show hardly any artistic development, making it difficult to assign them a date. ${ }^{66}$ That these low-cost paintings were an important part of his business model is evidenced by de Molijn's activities when he was appointed dean of the Haarlem Guild of Saint Luke. The colorful landscapes that were characterized by Stechow as outmoded show more variation. Remarkably enough, they often do bear dates and signatures, which implies that prospective buyers must have valued them as autograph paintings.

42 In her dissertation, Allen states that one of de Molijn's characteristics was his flexibility as an artist. She suggests that he worked in several different styles and techniques and that throughout his life he was able to respond to the demands of various iconographical challenges with the appropriate styles. ${ }^{67}$ That may be so. But a more important incentive must have been to improve his position in the contemporary art market by producing paintings for different prospective buyers. The landscapes that, according to Laurens Jan Bol and Hans Ulrich Beck, demonstrated a special quality quite different from the landscapes of Jan van Goyen and his followers, were more colorful and elaborate in execution and were therefore more expensive than de Molijn's monochrome landscapes with dunes. They appealed to wealthier clients who appreciated de Molijn's subtle references to such famous landscape painters of the past as Roelant Savery and Esaias van de Velde, and they reflected such contemporary trends as the intense golden light of Italianate landscape painting that he included from 1650 onward. De Molijn consciously borrowed elements from renowned landscape painters from the past and present, transforming them into something entirely his own. In doing so, he demonstrated the principles of creative imitation that we find described in contemporary artistic theory, for example, the treatise written by Franciscus Junius in $1641 .^{68}$ This is underlined by Reindert Falkenburg, who argues that painters did not generally turn to aggressive market strategies, such as innovation in the types of landscapes they painted; on the whole their strategy was defensive. They continued to make the most of types and alternatives that already existed. In his eyes: "the art market in the Golden Age did not encourage 
the invention of new types of paintings, but tolerated them." ${ }^{69}$

43 Finally, the question arises whether de Molijn's reputation with his contemporaries was based on his innovative monochrome landscapes produced around 1625. This can be deduced from the short descriptions of his work by Schrevelius and Houbraken. Schrevelius states in 1648 that de Molijn's work is comparable to that of Cornelis Vroom, who is now famous for his refined craftsmanship and the subtle lighting of his panoramic landscapes, features that cannot be compared to the quickly executed, monochrome landscapes of Jan van Goyen and his followers. ${ }^{70}$ One can therefore assume that Schrevelius was praising de Molijn for the colorful landscapes with figures that Wolfgang Stechow characterized as old-fashioned.

44 At the beginning of the 18th century, Houbraken praised de Molijn with the words cited at the start of this article: "clear in the way he rendered distances and glowing in his foregrounds." But what did he mean by "glowing in the foregrounds"? ${ }^{71}$ In his analysis of the term glow in Dutch artistic theory in the seventeenth century, Paul Taylor has shown that its meaning changed. In Gerard de Lairesse's Het groot Schilderboek of 1707, the author refers not only to achieving a "warm effect" in painting skin tissue, as was usual at the beginning of the seventeenth century, but also indicates that green and blue could be "glowing" colors as well. He explained this view in a chapter on "Forceful objects against weak backgrounds." De Lairesse emphasized that blue is a weak color, meaning that it is a color that recedes. An artist had to use pure green and blue in the foreground in combination with clear, but weaker colors and shadows in the distance, to create an effect of advancing rather than receding. ${ }^{72}$

45 De Lairesse explains the word glowing in the context of history painting, but this use of color can also be recognized in the panoramic landscapes with figures that de Molijn produced from 1640 onward. It can therefore be concluded that neither Schrevelius nor Houbraken praised de Molijn for his pioneering monochrome dune landscapes. Rather, they commended the pictures with a richer color scheme, subtle lighting, finely executed foliage, and robust figures that the artist painted later in life in conscious rivalry with landscape painters of the first decades of the seventeenth century.

\section{Conclusion}

46 While Pieter de Molijn is valued most by present-day art historians for the unpretentious monochrome landscapes he made for the open market, in his own day he was praised for his colorful landscapes, with their glowing foregrounds and subtle references to the works of such famous earlier landscape painters as Esaias van de Velde and Roelant Savery.

In the eyes of many art historians, the landscapes de Molijn produced after 1630 lacked the originality and panache of his pioneering tonal dune landscapes from around $1625 .{ }^{73}$ However, seventeenth-century sources point to the fact that de Molijn was a respected artist until the end of his life. His reputation as a landscape painter came close to that of Jan van Goyen. He owed this reputation to his refined craftsmanship and to his references to the tradition of landscape painting, both of which were valued by clients at the top end of the market. He was not a "conservative" because of his lack of talent but out of choice and artistic rivalry. He saw 
the commercial potential of combining low-cost production for the open market, while at the same time taking the risk of producing more time-consuming, well-crafted landscapes for richer clients, who must have been conscious of the fact that quality paintings could be the result of artistic rivalry. In the words of Franciscus Junius:

the artists who surpass all others are those who diligently pursue the old art with a new arrangement, thus adroitly bestowing their paintings with the pleasurable enjoyment of dissimilar similarity. ${ }^{74}$

It was not works like his Landscape with Dunes from 1626 (fig.1) that made de Molijn an outstanding artist for seventeenth-century art lovers, but rather paintings such as Peasants Returning Home, from 1647 (fig. 2), which ironically now slumbers in the depot of the Frans Hals Museum in Haarlem.

\section{Acknowledgements}

I am grateful to Nicolette Sluijter and Alison McNeil Kettering for their comments on the first versions of this article. Furthermore, I would like to thank the anonymous reviewers for their insightful and helpful suggestions. Finally, my thanks go to Marilyn Hedges for her corrections of my English.

Marion Boers is Senior Lecturer in early modern art history at the University of Leiden, specializing in the art market and prices of paintings in the Golden Age. She is the author of De Noord-Nederlandse kunsthandel in de eerste helft van de zeventiende eeuw (Hilversum: Verloren, 2012). At present she is doing research on art dealers, collections and the art market in Leiden and Amsterdam at the end of the sixteenth and the first decades of the seventeenth century.

\section{m.e.w.boers@hum.leidenuniv.nl}

\section{List of Illustrations}

Fig. 1 Pieter de Molijn, Landscape with Dunes and a Sandy Road, oil on panel, 26 x $36 \mathrm{~cm}$, signed and dated PMolyn 1626. Braunschweig, Herzog Ulrich-Museum, inv. 338 (artwork in the public domain)

Fig. 2 Pieter de Molijn, Peasants Returning Home, oil on canvas, 76 x $93.5 \mathrm{~cm}$, signed and dated PMolyn 1647. Haarlem, Frans Hals Museum, inv. o.s. 60-52 (artwork in the public domain; photo: Margareta Svensson)

Fig. 3 Pieter de Molijn, Landscape with Dunes and Travelers, oil on panel, 29 x $50 \mathrm{~cm}$, signed $P M$. Poznan, Museum Marodowe Poznaniu, inv. Mo 818 (artwork in the public domain) 
Fig. 4 Pieter de Molijn, Landscape with Dunes and Travelers, oil on panel, $28.6 \times 36.8 \mathrm{~cm}$, unsigned. Auction, Amsterdam, Christie's, May 14, 2002, no. 37 (artwork in the public domain)

Fig. 5 Pieter de Molijn, Travelers in Landscape with Dunes, oil on canvas, $39.5 \times 61 \mathrm{~cm}$, signed and dated PMolyn 1647. Whereabouts unknown (artwork in the public domain)

${ }^{1}$ Arnold Houbraken, De groote schouburgh der Nederlantsche konstschilders en schilderessen (Amsterdam: Houbraken, 1718-21), 1:215: "Pieter de Molyn was een fraai landschapschilder, helder in zyn verschieten, als ook natuurlijk gloeiend op de voorgronden."

2 The first monograph on the artist was published in Sweden in 1883: Olof Granberg, Pieter de Molijn (de Oude) och spåren af hans konst: En konsthistorisk studie (Stockholm: Gernandts, 1883). See also Olav [Olof] Granberg, "Pieter Molyn und seine Kunst," Zeitschrift für bildende Kunst 19 (1884): 369-77. Granberg was the first art historian to compare de Molijn's style with Jan van Goyen's, followed by Georg Kaspar Nagler, Johannes Immerzeel, and Gustav Friedrich Waagen. Granberg emphasized the independent position of Pieter de Molijn as a landscape painter. Wurzbach mentioned de Molijn at the beginning of the twentieth century together with Jan van Goyen and Esaias van de Velde as leading representatives of Dutch landscape painting: Alfred Wolfgang von Wurzbach, Niederländisches Künstler-Lexicon (Vienna and Leipzig: Halm und Goldmann, 1906-11), 2:179.

${ }^{3}$ Eva Jeney Allen in The Dictionary of Art, ed. Jane Turner et al. (London and New York: Grove, 1996), 2:826.

${ }^{4}$ Wolfgang Stechow, Dutch Landscape Painting of the Seventeenth Century (London: Phaidon, 1966), 26.

${ }^{5}$ Laurens Johannes Bol, Holländische Maler des 17. Jahrhunderts nahe der grossen Meister: Landschaften und Stilleben (Braunschweig: Klinkhardt \& Biemann, 1969), 139-41.

${ }^{6}$ Bol, Holländische Maler, 140. Biesboer also emphasizes the importance of this panoramic landscape and suggests that it was a source of inspiration for the young Jacob van Ruisdael: Pieter Biesboer, ed., Jacob van Ruisdael: De revolutie van het Hollandse landschap, exh. cat. (Haarlem: Frans Hals Museum and Hamburg: Kunsthalle 2002/Zwolle: Waanders, 2002), 96-97. In 1984 Bob Haak wrote that de Molijn "perhaps was the first to introduce a new phase in landscape painting, in any case before Jan van Goyen started to paint his monochrome landscapes." Furthermore, he stated that de Molijn, together with Cornelis Vroom influenced the artistic development of Salomon and Jacob van Ruisdael. Like Stechow, Haak underlined the importance of de Molijn's early monochrome paintings: Haak, Hollandse schilders in de Gouden Eeuw (Zwolle: Waanders, 1984), 240. In 1986 and 1987 Christopher Brown and Peter Sutton again underlined the importance of de Molijn as a pioneer of this type of landscape, when Pieter de Molijn's Landscape with Dunes' from 1626 was included in an exhibition in London and another held in Philadelphia, Boston, and Amsterdam. Both authors clearly subscribed to the viewpoints of Stechow and Haak on the artist; see Christopher Brown, Dutch Landscape: The Early Years, Haarlem and Amsterdam 1590-1650, exh. cat. (London: National Gallery, 1986), 22 and 151; and Peter Sutton, ed., Masters of 17th-Century Dutch Landscape Painting, exh. cat. (Amsterdam: Rijksmuseum; Boston: Museum of Fine Arts; and Philadelphia Museum of Art, 1987-88), 35-36 and 374-75. 
${ }^{7}$ Eva Jeney Allen, “The Life and Art of Pieter Molijn” (PhD diss., University of Michigan, 1987), 2. ${ }^{8}$ Allen, "Pieter Molijn," 93.

${ }^{9}$ Allen illustrated these assumptions by way of Roelant Savery's Mountain Landscape dated 1609, which inspired a de Molijn drawing many years later, and de Molijn's Winter Landscape from 1657, which was inspired by Hendrick Avercamp. Allen, "Pieter Molijn," 72 and 77.

${ }^{10}$ Hans Ulrich Beck, Künstler um Jan van Goyen (Doornspijk: Davaco, 1991), 273.

${ }^{11}$ Stechow, Dutch Landscape, 23, Allen, "Pieter Molijn," 1 and 42. See also Hans Ulrich Beck, Pieter Molijn: Katalog der Handzeichnungen (Doornspijk: Davaco, 1998), 17-18.

${ }^{12}$ Sluijter's publication was the result of a large project by the University of Amsterdam to study the cultural industries of Amsterdam in the Golden Age. Eric Jan Sluijter, Rembrandt's Rivals: History Painting in Amsterdam 1630-1650, Oculi: Studies in the Arts of the Low Countries 14 (Amsterdam and Philadelphia: John Benjamins Publishing, 2015), 3-5.

${ }^{13}$ Out of the forty-five painters Beck mentions in his Künstler um Jan van Goyen fourteen worked in Haarlem, not counting Salomon van Ruisdael, who was considered an equal to van Goyen and is therefore not one of the painters discussed in the book. This amounts to one-third of all the painters working in the same style as Jan van Goyen. To these can be added Italianate painters such as Nicolaes Berchem and Pieter van Laer and landscape painters such as Cornelis Vroom. ${ }^{14}$ Irene van Thiel-Stroman in Painting in Haarlem 1500-1850: The Collection of the Frans Hals Museum, Neeltje Köhler, Pieter Biesboer et al. (Ghent: Ludion, 2006), 246-47. The author refers to all the primary sources available.

${ }^{15}$ This can be concluded from an analysis of more than two hundred pupils of Haarlem artists between 1600 and 1650: Marion Boers-Goosens, "Schilders en de markt, Haarlem 1600-1635" (PhD diss., Universiteit Leiden, 2001), 100-104.

${ }^{16}$ Melanie Gifford, "Esaias van de Velde's Technical Innovations: Translating a Graphic Tradition into Paint," in Painting Techniques: History, Materials and Studio Practice (Dublin, 1998), 145-49, esp. 148.

${ }^{17}$ For example, a design for a print of a landscape with the ruins of the House of Kleef, engraved by Jan van de Velde II: F. W. H. Holstein, Dutch and Flemish Etchings, Engravings and Woodcuts, ca. 1450-1700 (Amsterdam: Hertzberger, 1949-), 33:56, no. 167. A second example is a design for a print showing the march of the Saint George militia to Hasselt on September 27, 1622. De Molijn received 24 pounds from the Haarlem magistrate and the design was later engraved by Gillis van Schyndel: Archief Van Kennemerland (AVK), Stads Archief (SA) 19/203 (Thesaurie rekeningen, 1623), fol. 64v.

${ }^{18}$ This is indicated by the fact that Samuel Ampzing did not mention him as a painter in his Het lof der stad Haerlem in Hollandt. Around 1654, at the end of his career, de Molijn showed a renewed interest in drawing and he produced his best works in this medium during that period; Beck, Molijn: Katalog der Handzeichnungen, 18. For the text by Samuel Ampzing, see note 28 below.

${ }^{19}$ We can also conclude this from the fact that the mayors of Haarlem entrusted him (together with Frans Hals and Jan van de Velde II) with visiting the infamous painter Johannes Torrentius in prison to find out whether his cell was equipped well enough to be a workshop. That same year the city magistrates awarded de Molijn the honorary commission to decorate the harpsichord of the city organist Cornelis Helmbreker with landscapes. He was paid the sizeable sum of 180 pounds.

${ }^{20}$ De Molijn's position in the artistic community is underlined by the fact that new guild rules, 
drawn up by Salomon de Bray in 1632, stipulated that only the most prominent of artists were qualified to lead the guild and that the board of governors should be chosen from "those whom the guild members consider to be the most competent and distinguished among the members (den geenen die sij tot sulckx de bequaemsten enden den gilden meest vorderlyckst achten)." Hessel Miedema, Archiefbescheiden van het St. Lucasgilde te Haarlem 1497-1798 (Alphen aan den Rijn: Canaletto, 1980), vol. 1, doc. A 42, p. 116, article 35.

${ }^{21}$ Miedema, Archiefbescheiden, vol. 1, doc. A 35, pp. 136-37. See also Marion Boers-Goosens, "Een nieuwe markt voor kunst: De expansie van de Haarlemse schilderijenmarkt in de eerste helft van de zeventiende eeuw," in Kunst voor de markt/Art for the Market 1500-1700, ed. Reindert Falkenburg, Nederlands Kunsthistorische Jaarboek 50 (1999): 202.

22 The Guild of Saint Luke was governed by a dean and two vinders. The dean had a leading position in representing the guild on official occasions. The vinders were responsible for the administration of the guild. Miedema, Archiefbescheiden, 2:1057. In 1637 and in 1649 he was appointed "vinder." On January 17, 1645, he is listed as "vinder" and on December 22 of that year as dean. ${ }^{23}$ For example, he appraised the important collection of notary Georgius van Velde in 1652 and, along with Frans Hals, and the paintings in the collection of the merchant and art collector Coenraet Coymans the year before he died.

${ }^{24}$ Allen, "Pieter Molijn," 42.

${ }^{25}$ We find his pictures on several lottery lists dating from the 1630s among works by other artists who produced low-cost monochrome paintings, such as Jan van Goyen and Salomon van Ruisdael. Moreover, in 1641 de Molijn asked the Haarlem magistrate for permission to sell paintings from his shop during the auction of his brother-in-law's estate. Local art dealers voiced their indignation, pointing to the fact that this was illegitimate competition: Miedema, Archiefbescheiden, vol. 1, doc. A 110 225; vol. 2, pp. 529-30; and vol. 1, doc. A 120, pp. 246-53, esp. articles 19-23 and 29. See Boers-Goosens, "Een nieuwe markt voor kunst," 195-219.

${ }^{26}$ Eric Jan Sluijter, "Jan van Goyen als marktleider, virtuoos en vernieuwer," in Jan van Goyen, exh. cat., ed. Christiaan Vogelaar (Leiden: Lakenhal, 1996-97/Zwolle: Waanders, 1996), 41-42. See also Constantijn Huygens, Mijn jeugd, ed. Christiaan Lambert Heesakkers (Amsterdam: Querido, 1987), 79.

${ }^{27}$ Jan Orlers, Beschrijvinge der Stadt Leyden (Leiden: Abraham Commelijn, 1641), 373-74.

${ }^{28}$ Ampzing named the following Haarlem artists in 1621: Wat wil ik oock van Dijck (painter of still-lifes Floris van Dijck), Van Wierigen (specialist marine painter Cornelis Claeszn van Wierigen) hier melden, de Grebbers (history and portrait painters Frans Pieterszn and Pieter de Grebber), Matham (engraver Jacob Matham), Pot (history and portrait painter Hendrick Gerritszn Pot), Ian Jacobs (Guldewaghen, a landscape painter who is now completely forgotten), Vroom (marine and landscape painter Cornelis Vroom) and Velde (engraver Jan van de Velde), de Halsen (portrait and genre painters Dirck and Frans Hals), Campen (architect and history painter Jacob van Campen), Smit (marine painter Cornelis Verbeeck, alias de Smit, who is almost completely forgotten), Brey (architect and history painter Salomon de Bray), Bouchorst (glass painter Jan van Bouckhorst) and Pieter Molyn.

${ }^{29}$ Samuel Ampzing, Beschrijvinge ende lof der stadt Haerlem in Hollandt (Haarlem: Rooman, 1628), 372. In the probate inventory of the notary Georgius van Velde, appraised by de Molijn himself in 1652, a painting is described as a landscape of Guldewaghen with images by Pieter de Molijn, for 54 guilders: Abraham Bredius, Künstler Inventare: Urkunden zur Geschichte der Holländischen Kunst des XVIten XVIIten und XVIIIten Jahrhunderts (The Hague: Nijhoff, 1915-22), 
1613. Jan Jacobszn Guldewaghen was the son of Jacob Janszn Guldewaghen, who was mentioned by Karel van Mander as an art lover. Schrevelius writes that he traveled to Italy. Guldewaghen lived in The Hague from 1630 on and was registered in the local painters' guild. In 1641 his estate was executed in The Hague by his heirs: Thieme Becker XV, 330.

${ }^{30}$ Theodorus Schrevelius, Harlemias, Ofte om beter te seggen, de eerste stichtinghe der stad Haerlem ... (Haarlem: Thomas Fonteyn, 1648), 390. "Nae dees volgen Iohan Iacobsz, die Italien ghesien heeft en andere Landtschaps-Schilders meer als ghemeen Reyer Niclaes Zuycker, Gerard Bleycker, Salomon Rustendael, en meer andere. (After these follow Iohan Iacobsz, who saw Italy and other mediocre landscape painters namely Reyer Niclaes Zuycker, Gerard Bleycker, Salomon Rustendael and more others)."

${ }^{31}$ Schrevelius, Harlemias, 389.

${ }^{32}$ In his treatise on painting, Samuel van Hoogstraeten wrote in 1678 about an imaginary competition between Jan van Goyen, François Knibbergen, and Jan Porcellis, who competed with each other to complete a picture in one day: Samuel van Hoogstraten, Inleyding tot de hooghe schoole der schilder-konst (Rotterdam: Fransois van Hoogstraten, 1678), 237-38.

${ }^{33}$ Houbraken, De groote schouburgh, 1:170 and 215.

${ }^{34}$ Sluijter, "Jan van Goyen als marktleider," 41-42.

${ }^{35}$ Sluijter names the inventories of Michiel Barrelbos and Bregitta Screvelius, appraised in Haarlem: Sluijter, "Jan van Goyen als marktleider," 41. For Pieter de Molijn, see the inventory of Louwijs Houwen, appraised in Amsterdam June 27, 1656; Getty Provenance Index: G.P.I., N-2215, with fifty-seven anonymous paintings besides a print by Jacob Matham and a "victorietje" by Pieter de Molijn.

${ }^{36}$ Getty Provenance Index: fourteen paintings were ascribed to Salomon van Ruisdael in eight different inventories. See also Boers-Goosens, "Schilders en de markt," 171.

${ }^{37}$ This is all the more interesting because most names that were noted by the appraisers were of Leiden-based artists, such as Gerard Dou and van Goyen himself for that matter, whereas Pieter de Molijn was one of the few artist recognized by the appraisers who lived and worked outside Leiden. Willemijn Fock, "Kunstbezit in Leiden in de $17^{\mathrm{e}}$ eeuw," in Het Rapenburg: Geschiedenis van een Leidse gracht, ed. Theo Lunsingh Scheurleer, Willemijn Fock, and Albert Jan van Dissel (Leiden: Universiteit Leiden, 1990), 12-14 (dl. Va); and Sluijter, "Jan van Goyen als marktleider," 55n29. Jan van Goyen is mentioned seventy-nine times and Pieter de Molijn less frequently, but with forty-five listings he comes third after van Goyen.

${ }^{38}$ In Amsterdam, twenty-one paintings in fourteen different inventories were ascribed to Jan van Goyen between 1629 and 1650 and twelve paintings by Pieter de Molijn in eleven inventories: Montias Database of probate inventories in Amsterdam (Frick Collection, online version).

${ }^{39}$ Drenth's wife Maritge Theunis also owned a small landscape in an ebony frame by de Molijn and a landscape by van Goyen acquired before the couple got married. The painter had a collection with works by artists from the sixteenth and early seventeenth centuries, such as Maarten van Heemskerck, Joos de Momper, Govert Janszn, and Gillis van Coninxloo. The only two contemporary painters in this inventory are Jan van Goyen and Pieter de Molijn: Bredius, Künstler Inventare, 288.

${ }^{40}$ These are the figures derived from the Montias Database at the Frick Collection. There are considerable discrepancies compared to Montias's 1991 article on paintings in Amsterdam inventories: John Michael Montias, "Works of Art in Seventeenth-Century Amsterdam," in Art in 
History/History in Art: Studies in Seventeenth-Century Dutch Culture, ed. David Freedberg and Jan de Vries (Santa Monica, Calif.: Getty Center for the History of Art and the Humanities, 1991), 364-67, tables 10a and 10b. There he found nine paintings in five different inventories that were ascribed to Jan van Goyen between 1620 and 1649 and eight by Pieter de Molijn in five inventories. According to Montias, in the same article, between 1650 and 1679 van Goyen was named twenty-two times in thirteen inventories and de Molijn twelve times in six.

${ }^{41}$ In 1647 the Guild of Saint Luke in The Hague organized a public auction of paintings that lasted almost a week. Around 850 works of art were sold, mostly by contemporary artists: ten were by Pieter de Molijn and twenty-three by Jan van Goyen: Bredius, Künstler Inventare, 457-530. There was also a copy after de Molijn in this auction. Seven paintings by Salomon van Ruisdael are mentioned in the auction book. De Molijn was not mentioned either in Delft or in Dordrecht, where several paintings were ascribed to Jan van Goyen. See John Loughman, "Een stad en haar kunstconsumptie: Openbare en privé-verzamelingen in Dordrecht 1620-1719," in De zichtbaere werelt: Schilderkunst uit de Gouden Eeuw in Hollands oudste stad, exh. cat., ed. P. Marijnissen (Dordrechts Museum, 1992 -93/Zwolle: Waanders, 1992), 48. Salomon van Ruisdael is not on Loughman's list. Before 1669 thirty-eight originals by Jan van Goyen and five copies after his work occur in Delft inventories, with a peak of twenty-two paintings in inventories dating from 1660. Pieter de Molijn and Salomon van Ruisdael were not among the twenty painters that were recognized most by the notary clerks in Delft. See John Michael Montias, Artists and Artisans in Delft: A Socio-Economic Study of the Seventeenth Century (Princeton, N.J.: Princeton University Press, 1982), 252.

${ }^{42}$ For example, Beck does not mention Jacob van Ruisdael in his monograph Künstler um Jan van Goyen in 1991, because he does not consider him to be a follower but rather an artist of the same quality as van Goyen himself.

${ }^{43}$ Sluijter, Rembrandt's Rivals, 19.

${ }^{44}$ One of the most important owners of works by Jan van Goyen mentioned by Sluijter was the wealthy painter and factory owner Jan van de Capelle. He possessed ten landscapes by van Goyen and also 417 drawings by the artist; Sluijter, "Jan van Goyen als marktleider," 41.

${ }^{45}$ Bredius, Künstler Inventare, 232, no. 178. De Renialme was an art dealer for the higher segment of the market. We can conclude this from the fact that he sent a list of all his paintings to Elector Friedrich Wilhelm of Prussia. See Friso Lammertse and Jaap van der Veen, Uylenburgh \& Zoon: Kunst en commercie van Rembrandt tot De Lairesse 1625-1675 (Zwolle: Waanders, 2006), 81, 256 and 275.

${ }^{46}$ For example Cornelis van Teylingen and Lodewijck van Alteren van Jaarsvelt. De Molijn's landscapes were bought by rich brewers, such as Gerrit Kinckhuysen and Bartholomeus van Brienen, and wealthy Haarlem merchants, such as Franchoys Maertens, Lucas de Clerq, and Adriaen Crommelingh. His work was represented in the collections of local notaries and lawyers, among others those of Pieter d'Assonville, Dirck Boortens, and Harmanus Capoen. Most of these individuals owned more than one painting by de Molijn, sometimes a pair, but sometimes four paintings or more. Getty Provenance Index: Lodewijk van Ateren van Jaarsvelt, G.P.I., N-2467, dated 1657; Pieter d'Assonville, G.P.I., N-1851, dated 1661; Dirck Boortens, G.P.I., N-5177, dated 1647; Bartel van Brienen, G.P.I., N-3911, dated 1653; Harmanus Capoen, G.P.I., N-2031, dated 1669; Lucas de Clerq, G.P.I., N-5364, dated 1640; Adriaen Crommelingh, G.P.I., N-3676, dated 1662; Gerrit Kinckhuysen, G.P.I., N-5305, dated 1668; Franchoys Maertens, G.P.I., N-5182, dated 1648; Cornelis van Teylingen, G.P.I., N-5363, dated 1640. 
${ }^{47}$ Abraham Bredius, “De schilder Johannes van de Capelle," Oud Holland 10 (1892): 37.

${ }^{48}$ Haak, Hollandse schilders, 365-66.

${ }^{49}$ De Molijn was not only an official appraiser in Haarlem but probably also an art dealer. He deposited paintings with the Amsterdam art dealer Johannes de Renialme; Bredius, Künstler Inventare, 1854. For the inventories of 1640 and 1657, see Bredius, Künstler Inventare, 232 (a landscape by de Molijn for fl. 30:0) and 233 (another landscape by de Molijn for fl. 24:0; and a landscape by van Goyen for fl. 48:0), but these prices are low compared to the landscape by Porcellis for fl. 150:0 (p. 231).

${ }^{50}$ See Marion Boers-Goosens, "De schilderijenverzameling van Baron Willem Vincent van Wyttenhorst," Oud Holland 117 (2004): 205-6.

${ }^{51} \mathrm{He}$ found a total of forty-six paintings by van Goyen that were appraised in probate inventories or sold during the 1647 auction of the Guild of Saint Luke in The Hague. The most expensive painting was in the estate of the Haarlem merchant and art collector Dirck Smuyser; Sluijter, "Jan van Goyen als marktleider," 42.

${ }^{52}$ In 1636 Cornelis Kittensteyn organized a lottery in Haarlem, which he advertised with three paintings by Jan van Goyen appraised by Salomon van Ruisdael (sic!) for 52, 50, and 48 guilders. In around 1640 a lottery list was published in Leiden by Jan van den Bosch with eight paintings by van Goyen with an average price of 34.25 guilders.

${ }^{53}$ Marion Boers-Goosens, "Prices of Northern Netherlandish Paintings in the Seventeenth Century," in In His Milieu: Essays on Netherlandish Art in Memory of John Michael Montias, ed. Amy Golany (Amsterdam: Amsterdam University Press, 2006), 66-67.

${ }^{54}$ Sources: Bredius, Künstler Inventare; Montias Database at the Frick Collection (Amsterdam inventories); and the Getty Provenance Index.

${ }^{55}$ Gemeente Archief Amsterdam (GAA) 570. 4921, ff. 140-64v, notary Laurens Lamberti (G.P.I., $\mathrm{N}-2278$, dated October 3, 1647). In 1652, de Molijn appraised the paintings of the Haarlem notary Georgius van Velde. On the list was a landscape by Guldewaghen with figures by de Molijn for fl. 54:0.

${ }^{56}$ Gemeente Archief Amsterdam (GAA) 1713, fol. 44, fl. 13:6 (G.P.I., N-2132, dated January 3, $1660)$.

${ }^{57}$ In 1650 Van Vliet in Delft owned a small painting by de Molijn for fl. 3:5 (Bredius, Künstler Inventare, 1440); in 1656 Abraham de Pape in Leiden one for fl. 8:0 (Bredius, Künstler Inventare, 1860); in 1656 Louwies Houwen one in Amsterdam for fl. 8:0 (G.P.I., N-2215); and in 1660 Willem Bus one in Amsterdam for fl. 3:0 (G.P.I., N-2132).

${ }^{58}$ The average price of landscapes by de Molijn in the 1647 sale in The Hague was also marginally lower than the price of those of Jan van Goyen: 16.34 guilders. The auction book mentions six paintings by Pieter de Molijn, three without a price. The lowest price is fl. 6:15, the highest price is fl. 26:10. Compare the price of a "principael van Terburch" (Ter Borch) for fl. 50:0 in this auction: Bredius, Künstler Inventare, 468, no. 156.

${ }^{59}$ The lowest amount for a painting by Pieter de Molijn was for a small landscape worth fl. 21:00, the highest fl. 96:00 for a "large round painting." For example, the van Goyens in the lottery of Jan van den Bosch around 1640 in Leiden varied between 15 and 78 guilders and the works by de Molijn were a bit more expensive, being estimated between 21 and 85 guilders. See Fock in Rapenburg, ed. Lunsingh Scheurleer, Fock and van Dissel, 32. 
${ }^{60}$ Eleven landscapes by Pieter de Molijn occur in the lottery list of Ian Pieterszn van den Bosch, dated ca. 1640. The small paintings are estimated at prices around fl. 20:0 and the large ones around fl. 80:0. Unfortunately there are no landscapes by Salomon van Ruisdael on this list. However, work by van Ruisdael was in Haarlem lotteries dated 1634 and 1636. The prices mentioned on these lists are higher and comparable to those for paintings by Pieter de Molijn. Two large landscapes were priced at fl. 90:0 and a small landscape at fl. 16:0. The average price of the six paintings by Salomon van Ruisdael was much higher than for Molijn's landscapes: fl. 60.33, but this average is based on less data and is moreover the result of the fact that two of the paintings are large landscapes with the relatively high price of fl. 90:0. For the lottery of J. P. van den Bosch in Valkenburg in ca 1640, see Fock in Rapenburg, ed. Lunsingh Scheurleer, Fock, and van Dissel, 32. For the two lotteries in Haarlem, dating from 1634 and 1636, see Miedema, Archiefbescheiden, $1: 157-58$ and 194-95.

${ }^{61}$ G.P.I., N-2278, dated October 3, 1647.

${ }^{62}$ This is the case in the estate of Leendert Gysbertszn Bardenis, dated 1647. He owned three originals by Pieter de Molijn, valued at fl.10:0, fl. 12:0, and fl. 32:0, compared to four landscapes by van Goyen for fl. 16:0, fl. 20:0 (twice), and fl. 22:0. See G.P.I., N-5177. Compare the inventories of Franchoijs Maertens, dated June 23, 1648 (G.P.I., N-5182): “principalen” by de Molijn, fl. 8:0 and fl. 12:0; "principael" by Jan van Goyen, fl. 15:0; of Dirck Smuyser, dated January 23, 1653(G.P.I., N-3713): two paintings by de Molijn, fl. 42:0 and fl. 20:0, one by Jan van Goyen, fl. 54:0; of Lodewijck van Alteren van Jaersvelt, dated 1657 (G.P.I., N-2467): two landscapes by de Molijn at fl. 10:0 and fl. 30:0 fl., landscapes by Jan van Goyen, fl. 10:0, fl.14:0, and fl. 30:0; of Johan Schade in Utrecht, dated August 31, 1658 (G.P.I., N-1749): two landscapes by de Molijn, fl. 12:0 and fl. 23:0, and one by van Goyen for fl. 20:0 . Also compare the landscape by de Molijn valued at fl. 24:0 in the inventory of Johannes de Renialme, dated December 20, 1657 (G.P.I., N-2213) to the landscape of Jan van Goyen listed in the same inventory for fl. 48:0.

${ }^{63}$ Until 1665 the average price of a landscape by Pieter de Molijn was 18.85 guilders, but for Salomon van Ruisdael it came to 10 guilders. This changed after 1665, when prices for paintings by Pieter de Molijn started to drop, whereas the highest appraisals for landscapes by Salomon van Ruisdael were noted during the final decades of the seventeenth century (although the average remained lower than for de Molijn's landscapes at a sum of 13 guilders); Boers-Goosens, "Schilders en de markt," 311. See also Alain Chong, "The Market for Landscape Painting in Seventeenth-Century Holland," in Masters of Dutch Landscape, ed. Sutton, 118. Based on six prices, he calculated an average of fl. 8.7 for the period 1651-75 and based on five prices, an average of fl. 12.4 for the period from 1676 to 1700 . Dirck Smuyser owned five works by Salomon van Ruisdael at an average value of 13 guilders in 1668. In the same year, a landscape by van Ruisdael was appraised at 20 guilders, the highest valuation for a landscape by Salomon van Ruisdael in the seventeenth century; the inventory of Gerrit Kinckhuysen dated September 5, 1668 (G.P.I., N-5305). ${ }^{64}$ Eric Jan Sluijter, "Over Brabantse vodden, economische concurrentie, artistieke wedijver en de groei van de markt voor schilderijen in de eerste decennia van de zeventiende eeuw," in Kunst voor de markt/Art for the Market 1500-1700, ed. Reindert Falkenburg, Nederlands Kunsthistorische Jaarboek 50 (1999): 123 and 125-26. Also published in translation: JHNA 1, no. 2 (2009). Melanie Gifford. "Esaias van de Velde's Technical Innovations: Translating a Graphic Tradition into Paint." In Painting Techniques: History, Materials and Studio Practice, 145-49 (Dublin, 1998). ${ }^{65}$ For Joris van Oorschot inventory, see Montias Database at the Frick Collection (online): dated 
June 30, 1671, Gemeente Archief Amsterdam (GAA), Notarieel Archief (NA) 1495, fol 189v.

${ }^{66}$ Allen, "Pieter Molijn," 82

${ }^{67}$ Allen, "Pieter Molijn," 2.

${ }^{68}$ Sluijter, Rembrandt's Rivals, 70 and n. 252 (for Junius).

${ }^{69}$ Reindert Falkenburg, "Onweer bij Jan van Goyen: Artistieke wedijver en de markt voor het Hollandse landschap in de 17 de eeuw," in Natuur en landschap in de Nederlandse kunst 1500-1850, ed. Falkenburg, Nederlands Kunsthistorisch Jaarboek 48 (1997): 143.

70 "Onder de Landtschaps-Schilders is noch in 't leven Cornelis Vroom, die in 't sijn sijn vader niet en wijckt. Men houdt het daer voor dat hy alsoo uyt-steeckt in syn kunst dat hy qualijck niemandt sijns gelijck heeft van die noch leven hoewel Pieter de Moulijn, nae 't oordeel van veele hem seer nae komt, jae in gelijcke graed (Among the landscape painters still lives Cornelis Vroom, who equals his father. People maintain that he stands out so much in his art that there is hardly anyone like him among living artists, although Pieter de Molijn, according to many, comes very close in equaling him)." Schrevelius, Harlemias, 389.

${ }^{71}$ Arnold Houbraken, De groote schouburgh, 1:215. "Pieter de Molyn was een fraai landschapschilder, helder in zyn verschieten, als ook natuurlijk gloeiend op de voorgronden (Pieter de Molyn is a fine landscape painter, clear in his distances and naturally glowing in the foreground)."

${ }^{72}$ For the term glowing in seventeenth-century Dutch painting, see Paul Taylor, "The Glow in Late Sixteenth and Seventeenth Century Dutch Landscape," in Looking through Paintings: The Study of Painting Techniques and Materials in Support of Art Historical Research, ed. Erna Hermens, Leids Kunsthistorisch Jaarboek 11(1998): 174-75.

${ }^{73}$ Beck, Pieter Molijn: Katalog der Handzeichnungen, 14.

${ }^{74}$ Franciscus Junius, De schilderkonst der ouden, begrepen in drie boecken (Middelburg, 1641), 29 (translation: Eric Jan Sluijter).

\section{Bibliography}

Allen, Eva Jeney. “The Life and Art of Pieter Molijn.” PhD diss., University of Michigan, 1987.

Ampzing, Samuel [?]. Het lof der stad Haerlem in Hollandt. Haarlem 1621

Ampzing, Samuel. Beschrijvinge ende lof der stadt Haerlem in Hollandt. Haarlem: Rooman, 1628.

Beck, Hans Ulrich. Künstler um Jan van Goyen, Doornspijk: Davaco, 1991.

Beck, Hans Ulrich. Pieter Molijn: Katalog der Handzeichnungen. Doornspijk: Davaco, 1998.

Biesboer, Pieter, ed. Jacob van Ruisdael: De revolutie van het Hollandse landschap. Exh. cat. Haarlem: Frans Hals Museum and Hamburg: Kunsthalle, 2002/Zwolle: Waanders, 2002.

Boers-Goosens, Marion. "De schilderijenverzameling van Baron Willem Vincent van Wyttenhorst." Oud Holland 117 (2004): 181-243.

Boers-Goosens, Marion. "Een nieuwe markt voor kunst: De expansie van de Haarlemse schilderi- 
jenmarkt in de eerste helft van de zeventiende eeuw." In Kunst voor de markt/Art for the Market 1500-1700. Edited by Reindert Falkenburg, 194-219. Nederlands Kunsthistorische Jaarboek 50 (1999).

Boers-Goosens, Marion. "Prices of Northern Netherlandish Paintings in the Seventeenth Century." In In His Milieu: Essays on Netherlandish Art in Memory of John Michael Montias. Edited by Amy Golany, 59-71. Amsterdam: Amsterdam University Press, 2006.

Boers-Goosens, Marion. “Schilders en de markt, Haarlem 1600-1635.” PhD diss., Universiteit Leiden, 2001.

Bol, Laurens Johannes. Holländische Maler des 17. Jahrhunderts nahe der grossen Meister: Landschaften und Stilleben. Braunschweig: Klinkhardt \& Biemann, 1969.

Bredius, Abraham. “De schilder Johannes van de Capelle.” Oud Holland 10 (1892): 133-36.

Bredius, Abraham. Künstler Inventare: Urkunden zur Geschichte der Holländischen Kunst des XVIten XVIIten und XVIIIten Jahrhunderts. The Hague: Nijhoff, 1915-22.

Brown, Christopher. Dutch Landscape: The Early Years, Haarlem and Amsterdam 1590-1650. Exh cat. London: National Gallery, 1986.

Falkenburg, Reindert. "Onweer bij Jan van Goyen: Artistieke wedijver en de markt voor het Hollandse landschap in de $17^{\text {de }}$ eeuw." In Natuur en landschap in de Nederlandse kunst, 1500-1850, 117-61. Nederlands Kunsthistorisch Jaarboek 48 (1997).

Gifford, Melanie. "Esaias van de Velde’s Technical Innovations: Translating a Graphic Tradition into Paint." In Painting Techniques: History, Materials and Studio Practice, 145-49. Dublin, 1998.

Granberg, Olof. Pieter de Molijn (de Oude) och spåren af hans konst: En konsthistorisk studie. Stockholm: Gernandts, 1883.

Granberg, Olof. "Pieter Molyn und seine Kunst.” Zeitschrift für bildende Kunst 19 (1884): 369-77.

Haak, Bob. Hollandse schilders in de Gouden Eeuw. Zwolle: Waanders 1984.

Hollstein, Friedrich Wilhelm Dutch and Flemish Etchings, Engravings and Woodcuts, ca. 14501700, Amsterdam: Hertzberger, 1949- .

Hoogstraten, Samuel van. Inleyding tot de hooghe schoole der schilder-konst. Rotterdam: Fransois van Hoogstraten, 1678.

Houbraken, Arnold. De groote schouburgh der Nederlantsche konstschilders en schilderessen. 3 vols. Amsterdam: Houbraken, 1718-21. 
Huygens, Constantijn. Mijn jeugd. Edited by Christiaan Lambert Heesakkers. Amsterdam: Querido, 1987.

Junius, Franciscus. De schilderkonst der ouden, begrepen in drie boecken. Middelburg: Zacharias Roman 1641.

Köhler, Neeltje, Biesboer, Pieter, et al. Painting in Haarlem 1500-1850: The Collection of the Frans Hals Museum. Ghent: Ludion, 2006.

Lammertse, Friso, and Jaap van der Veen, Uylenburgh \& Zoon: Kunst en commercie van Rembrandt tot De Lairesse 1625-1675. Zwolle: Waanders, 2006.

Lunsingh Scheurleer, Theo, Willemijn Fock, and Albert Jan van Dissel, eds. Het Rapenburg: Geschiedenis van een Leidse gracht. Leiden: Universiteit Leiden, 1990.

Marijnissen, Peter, et. al. De zichtbaere werelt: Schilderkunst uit de Gouden Eeuw in Hollands oudste stad. Exh. cat. Dordrechts Museum, 1992-93/Zwolle: Waanders, 1992.

Miedema, Hessel. Archiefbescheiden van het St. Lucasgilde te Haarlem 1497-1798. 2 vols. Alphen aan den Rijn: Canaletto, 1980.

Montias, John Michael. Artists and Artisans in Delft: A Socio-Economic Study of the Seventeenth Century. Princeton, N.J.: Princeton University Press, 1982.

Montias, John Michael. "Works of Art in Seventeenth-Century Amsterdam.” In Art in History/ History in Art: Studies in Seventeenth-Century Dutch Culture. Edited by David Freedberg and Jan de Vries, 331-72. Santa Monica, Calif.: Getty Center for Art History and the Humanities, 1991.

Orlers, Jan. Beschrijvinge der Stadt Leyden. Leiden: Abraham Commelijn, 1641.

Schrevelius, Theodorus. Harlemias, Ofte om beter te seggen, de eerste stichtinghe der stad Haerlem . .. Haarlem: Thomas Fonteyn, 1648.

Sluijter, Eric Jan. “Jan van Goyen als marktleider, virtuoos en vernieuwer." In Jan van Goyen. Exh. cat. Edited by Christiaan Vogelaar, 38-59. Leiden: Lakenhal 1996-97/Zwolle: Waanders, 1996.

Sluijter, Eric Jan. "Over Brabantse vodden, economische concurrentie, artistieke wedijver en de groei van de markt voor schilderijen in de eerste decennia van de zeventiende eeuw." In Kunst voor de markt/Art for the Market 1500-1700. Edited by Reindert Falkenburg, 112-43. Nederlands Kunsthistorische Jaarboek 50 (1999).

Sluijter, Eric Jan. Rembrandt's Rivals: History Painting in Amsterdam 1630-1650. Oculi: Studies in the Arts of the Low Countries 14. Amsterdam and Philadelphia: John Benjamins Publishing, 
2015.

Stechow, Wolfgang. Dutch Landscape Painting of the Seventeenth Century. London: Phaidon, 1966.

Sutton, Peter, ed. Masters of 17th-century Dutch Landscape Painting. Exh. cat. Amsterdam: Rijksmuseum; Boston: Museum of Fine Arts; and Philadelphia Museum of Art, 1987-88.

Taylor, Paul. "The Glow in Late Sixteenth and Seventeenth Century Dutch Landscape." In Looking through Paintings: The Study of Painting Techniques and Materials in Support of Art Historical Research. Edited by Erna Hermens, 159-78. Leids Kunsthistorisch Jaarboek 11 (1998).

Turner, Jane, et al. The Dictionary of Art. London and New York: Grove, 1996.

Wurzbach, Alfred Wolfgang von. Niederländisches Künstler-Lexicon. Vienna and Leipzig: Halm und Goldmann, 1906-11.

Recommended Citation:

Marion Boers, "Pieter de Molijn (1597-1661): A Dutch Painter and the Art Market in the Seventeenth Century," Journal of Historians of Netherlandish Art 9:2 (Summer 2017) D0l: 10.5092/jhna.2017.9.2.5 